\title{
Effects of forage family on apparent ruminal synthesis of $B$ vitamins in lactating dairy cows
}

\author{
D. S. Castagnino, ${ }^{*} \dagger^{1}$ M. Seck, ${ }^{*} \dagger^{1}$ V. Beaudet, ${ }^{*} \dagger$ K. L. Kammes, $\ddagger$ J. A. Voelker Linton, $\ddagger$ M. S. Allen, $\ddagger$ \\ R. Gervais, $†$ P. Y. Chouinard, $†$ and C. L. Girard ${ }^{* 2}$ \\ *Sherbrooke Research and Development Centre, 2000 College, Sherbrooke, QC, Canada, J1M 0C8 \\ †Département des sciences animales, Université Laval, 2425 rue de l'Agriculture, Québec, Québec, Canada, G1V 0A6 \\ ‡Department of Animal Science, Michigan State University, East Lansing 48824-1225
}

\begin{abstract}
Effects of forage family (legume vs. grass) on apparent ruminal synthesis (ARS) and postruminal supply of $\mathrm{B}$ vitamins were evaluated in 2 experiments. Diets containing either alfalfa (AL) or orchardgrass (OG) silages as the sole forage were offered to ruminally and duodenally cannulated lactating Holstein cows in crossover design experiments. Experiment 1 compared diets containing AL and $\mathrm{OG}[\sim 23 \%$ forage neutral detergent fiber (NDF) and $\sim 27 \%$ total NDF] offered to 8 cows in two 15 -d treatment periods. Experiment 2 compared diets containing $\mathrm{AL}$ and $\mathrm{OG}(\sim 25 \%$ forage $\mathrm{NDF}$ and $\sim 30 \%$ total NDF) offered to 13 cows in two 18-d treatment periods. Thiamin, riboflavin, niacin, vitamin $\mathrm{B}_{6}$, folates, and vitamin $\mathrm{B}_{12}$ were analyzed in feeds and duodenal digesta. Apparent ruminal synthesis was calculated as the duodenal flow of each vitamin minus its intake. Forage family affected B vitamin intakes, duodenal flow, and ARS. In both experiments, AL diets increased vitamin $\mathrm{B}_{6}$ and decreased folate intakes. In experiment 1 , riboflavin and niacin intakes were greater with the OG diet, whereas in experiment 2 thiamin intake was greater but riboflavin intake was smaller with the OG diet. In spite of the low contribution of either silage to the dietary folate content, folate intake was greater with OG diets than AL due to the difference in soybean meal contribution between diets. Niacin and folate ARS were not affected by the forage family. Duodenal microbial nitrogen flow was positively correlated with ARS of riboflavin, niacin, vitamin $\mathrm{B}_{6}$, folates, and vitamin $\mathrm{B}_{12}$, but tended to be negatively correlated with thiamin ARS. Apparent ruminal synthesis of fo-
\end{abstract}

Received August 27, 2015.

Accepted November 23, 2015.

${ }^{1}$ Both authors contributed equally to this study.

${ }^{2}$ Corresponding author: Christiane.Girard@agr.gc.ca lates and vitamin $\mathrm{B}_{12}$ appear to be related to microbial biomass activity. Changes in nutrient composition of the diets likely affected the microbial population in the rumen and their B vitamin metabolism.

Key words: apparent ruminal synthesis, B vitamin, dairy cow, forage family

\section{INTRODUCTION}

Studies on B vitamin requirements of cattle, conducted more than $60 \mathrm{yr}$ ago, concluded that mature ruminants with a functional rumen did not require B vitamin supplements because the amounts of vitamins provided by the diet or synthesized by rumen microorganisms were sufficient to avoid apparition of deficiency symptoms (Bechdel et al., 1926; Kon and Porter, 1954). However, deficiency symptoms are the last stage of the deficiency; deficiency appears as soon as the supply is inferior to the needs, leading to biochemical changes (Combs, 2012). Reports of positive production responses to B vitamin supplementation in high-producing dairy cows (Girard and Matte, 1998, 2005; Schwab et al., 2005; Chen et al., 2011) suggest that, under some conditions, the need for B vitamins frequently exceed the supply from the diet and the synthesis by rumen microbes, leading to suboptimal milk production and metabolic efficiency. Shaver and Bal (2000) reported that supplementing dietary thiamin increased milk and component yields. A meta-analysis showed that a niacin supplement increased milk fat and protein yields and tended to increase feed efficiency (Schwab et al., 2005). Supplementary folic acid increased milk production of cows in the second lactation or greater (Girard and Matte, 1998). Girard and Matte (2005) observed that, when compared with a supplement of folic acid alone, a combined supplement of folic acid and vitamin $\mathrm{B}_{12}$ increased milk and milk component yields in primiparous cows during early lactation. However, some studies observed no effect of vitamin supplements (Rosendo et al., 2004; Girard et al., 2005). 
A better understanding of dietary factors driving the fate of B vitamins in rumen of dairy cows is essential to define their B vitamin requirements. A limited number of studies have looked at the effects of dietary factors, such as forage-to-concentrate ratio or grain processing, on production of $\mathrm{B}$ vitamins by the ruminal microflora (Conrad and Hibbs, 1954; Hayes et al., 1966; Breves et al., 1981; Abel et al., 2001), but to our knowledge, no data are available on the effects of forage family. The objective of the present study was to describe the effect of forage family (legume or grass) on B-vitamin supply and apparent ruminal synthesis (ARS) in lactating dairy cows.

\section{MATERIALS AND METHODS}

Experimental procedures of the 2 studies were conducted on cows from the Michigan State University Dairy Cattle Teaching and Research Center, and approved by the Institutional Animal Care and Use Committee at Michigan State University (East Lansing, MI). Prior to calving, cows were cannulated ruminally (Bar Diamond Inc., Parma, ID) and duodenally with a gutter-type $\mathrm{T}$ cannula placed approximately $10 \mathrm{~cm}$ distal to the pylorus (Joy et al., 1997). Surgery was performed at the Department of Large Animal Clinical Science, College of Veterinary Medicine, Michigan State University. Experimental procedures, measurements, and analyses were described in detail by Voelker Linton and Allen (2008; experiment 1), and Kammes and Allen (2012; experiment 2).

\section{Experiment 1}

Cows and Treatments. Eight multiparous cows were assigned randomly to treatment sequence in a crossover design with a 14-d preliminary period followed by two 15-d treatment periods. The 2 treatments were diets containing either alfalfa (AL; Medicago sativa L.) silage, harvested at early bud stage, or orchardgrass (OG; Dactylis glomerata L.) silage, harvested at early boot stage as sole forage (Table 1). As both diets were formulated to contain $27 \% \mathrm{NDF}$ and $23 \%$ forage NDF (Voelker Linton and Allen, 2008), the forage-toconcentrate ratios were 53:47 and 48:52 for AL and OG, respectively. Cows were fed ad libitum a TMR served once daily $(1100 \mathrm{~h})$ at $110 \%$ of expected intake.

Sample and Data Collection. Individual feed intake was recorded daily. From d 11 to 13 of each period, samples of each dietary ingredient were collected daily and mixed into one sample per period. Duodenal digesta was collected every $9 \mathrm{~h}$ during these $3 \mathrm{~d}$. All samples were stored at $-20^{\circ} \mathrm{C}$.

\section{Experiment 2}

Cows and Treatments. Thirteen multiparous cows were assigned randomly to treatment sequence in a crossover design with a 14-d preliminary period followed by two 18-d treatment periods. The 2 treatments were diets containing either AL silage harvested at early to midbloom stage or OG silage harvested at early head stage as sole forage (Table 1). Both diets were formulated to contain $30 \% \mathrm{NDF}$ and $25 \%$ forage NDF (Kammes and Allen, 2012). Consequently, the forage-to-concentrate ratio differed between diet, from 60:40 and 43:57 for AL and OG, respectively. Cows were fed ad libitum a TMR served once daily $(1130 \mathrm{~h})$ at $110 \%$ of expected intake.

Sample and Data Collection. Individual feed intake was recorded daily. From d 11 to 15 of each period, samples of each dietary ingredient were collected daily and mixed into 1 sample per period. Duodenal samples were collected every $15 \mathrm{~h}$ during these $5 \mathrm{~d}$. All samples were stored at $-20^{\circ} \mathrm{C}$.

Laboratory Analyses. Frozen duodenal digesta samples were combined into one sample per cow per period, finely chopped using a commercial food processor (84142 Food cutter; Hobart Manufacturing Co., Troy, $\mathrm{OH})$, and a representative subsample was lyophilized. Dietary ingredients were dried at $55^{\circ} \mathrm{C}$ in a forced-air oven for $72 \mathrm{~h}$. All samples were ground with a Wiley mill (1-mm screen, Arthur H. Thomas, Philadelphia, $\mathrm{PA})$.

Concentrations of $\mathrm{B}$ vitamins in feed and duodenal digesta were analyzed at the Sherbrooke Research and Development Centre (Sherbrooke, Québec, Canada). Thiamin, riboflavin, niacin, and vitamin $\mathrm{B}_{6}$ were analyzed on HPLC (Varian Prostar, Lake Forest, CA) with a solvent delivery system (model 210), an autosampler (model 410), and a fluorescence detection system (model 363). Folates were analyzed with a microbiological microtiter plate test (VitaFast Folic Acid, R-Biopharm Inc., Marshall, MI), and vitamin $\mathrm{B}_{12}$ was analyzed by radio-assay [SimulTRAC-S Vitamin $\mathrm{B}_{12}\left({ }^{57} \mathrm{Co}\right) /$ Folate $\left({ }^{125} \mathrm{I}\right)$, MP Biomedicals, Solon, OH]. All samples were analyzed in duplicates (except for folates which were analyzed in triplicates), and a coefficient of variation of less than $10 \%$ was accepted between replicates.

Thiamin. Thiamin concentrations were analyzed by HPLC according to a method adapted from Bötticher and Bötticher (1986). Standard curves were prepared as followed: a standard stock solution was prepared by dissolving $33.7 \mathrm{mg}$ of thiamin hydrochloride (No. T4562, Sigma-Aldrich, Oakville, ON, Canada) in 100 $\mathrm{mL}$ of $0.1 \mathrm{M} \mathrm{H}_{2} \mathrm{SO}_{4}$ (No. 35129812, Fisher Scientific, Ottawa, ON, Canada). Then, $400 \mu \mathrm{L}$ of the solution were diluted in $1,600 \mu \mathrm{L}$ of ultrapure water to obtain 
an initial concentration of $200 \mu M$ thiamin, which was used to obtain a 7-level standard curve $(0.3,0.6,1.3$, $2.6,3.8,5.0$, and $7.5 \mu M$ ). For the feed and digesta, $0.1 \mathrm{~g}$ of sample and $5 \mathrm{~mL}$ of $0.1 \mathrm{M} \mathrm{H}_{2} \mathrm{SO}_{4}$ were mixed in a $15-\mathrm{mL}$ polypropylene conical tube and autoclaved $\left(100^{\circ} \mathrm{C}, 15 \mathrm{~min}\right)$. After cooling in an ice bath, $\mathrm{pH}$ was adjusted to 4.5 with $4.0 M$ sodium acetate (No. S8750, Sigma-Aldrich) buffer and $500 \mu \mathrm{L}$ of $1 \%$ reduced glutathione (No. G4251, Sigma-Aldrich) were added in each tube. Next, according to the methods adapted from Hyun and Tamura (2005) and Jakobsen (2008), $1 \mathrm{~mL}$ of an aqueous trienzyme mix was added, containing $60 \mathrm{U}$ of papain (No. P3250, Sigma-Aldrich), 10,167 U of $\alpha$-amylase (No. A9857, Sigma-Aldrich), and $14 \mathrm{U}$ of acid phosphatase (No. P3752, Sigma-Aldrich). The samples were incubated $(60 \mathrm{~min})$ in an ultrasonic bath (Ultrasonic Cleaners, $40 \mathrm{kHz}$, Cole-Parmer, Montréal, QC, Canada) and then autoclaved to inactivate the enzymes $\left(100^{\circ} \mathrm{C}, 5 \mathrm{~min}\right)$. After cooling in an ice bath, the volume was completed to $7 \mathrm{~mL}$ with ultrapure water and centrifuged $\left(900 \times g, 10 \mathrm{~min}, 4^{\circ} \mathrm{C}\right)$. Immediately following centrifugation, the supernatant $(1 \mathrm{~mL})$ was

Table 1. Ingredients, nutrient composition, and B-vitamin concentrations of the 2 treatment diets containing alfalfa silage $(\mathrm{AL})$ or orchardgrass silage $(\mathrm{OG})$ as sole forage in experiments 1 and $2^{1}$

\begin{tabular}{|c|c|c|c|c|}
\hline \multirow[b]{2}{*}{ Item } & \multicolumn{2}{|c|}{ Experiment 1} & \multicolumn{2}{|c|}{ Experiment 2} \\
\hline & $\mathrm{AL}$ & $\mathrm{OG}$ & $\mathrm{AL}$ & OG \\
\hline \multicolumn{5}{|l|}{ Ingredient, $\%$ of $\mathrm{DM}$} \\
\hline Alfalfa silage & $53.0^{2}$ & - & $59.9^{3}$ & - \\
\hline Orchardgrass silage & - & $47.9^{4}$ & - & $42.7^{5}$ \\
\hline Dry ground corn & 36.3 & 40.3 & 33.6 & 36.6 \\
\hline Soybean meal (48\% CP) & 6.50 & 7.00 & - & 11.8 \\
\hline Vitamin and mineral mix & 4.20 & 4.20 & 2.50 & 3.39 \\
\hline SoyPlus ${ }^{8}$ & 1.30 & 1.30 & 3.99 & 3.99 \\
\hline Blood meal & 0.30 & 0.90 & - & - \\
\hline Limestone & - & 0.40 & - & 0.30 \\
\hline Urea & - & 0.20 & - & 1.20 \\
\hline \multicolumn{5}{|l|}{ Nutrient } \\
\hline DM, $\%$ as fed & 43.6 & 50.6 & 54.5 & 52.3 \\
\hline $\mathrm{OM}, \%$ of $\mathrm{DM}$ & 91.5 & 91.5 & 92.7 & 91.1 \\
\hline $\mathrm{NDF}, \%$ of $\mathrm{DM}$ & 26.7 & 27.5 & 29.2 & 30.2 \\
\hline Forage NDF, $\%$ of DM & 22.5 & 23.0 & 25.3 & 24.9 \\
\hline Indigestible NDF, $\%$ of DM & 14.8 & 7.90 & 14.8 & 8.24 \\
\hline Starch, \% of DM & 30.2 & 32.1 & 27.3 & 29.6 \\
\hline $\mathrm{CP}, \%$ of $\mathrm{DM}$ & 18.3 & 18.8 & 18.4 & 17.0 \\
\hline \multicolumn{5}{|c|}{ B-vitamin concentrations, $\mathrm{mg} / \mathrm{kg}$ of DM } \\
\hline Thiamin & 2.38 & 2.31 & 2.89 & 2.20 \\
\hline Riboflavin & 36.93 & 46.07 & 66.95 & 20.50 \\
\hline Niacin $^{9}$ & 22.32 & 56.44 & 46.70 & 50.60 \\
\hline Vitamin $\mathrm{B}_{6}{ }^{10}$ & 17.63 & 11.84 & 7.38 & 3.36 \\
\hline Folates & 0.36 & 0.46 & 0.36 & 0.44 \\
\hline Vitamin $B_{12}$ & $\mathrm{ND}^{11}$ & ND & 0.001 & 0.002 \\
\hline
\end{tabular}

${ }^{1}$ Adapted from Voelker Linton and Allen (2008) and Kammes and Allen (2012).

${ }^{2} \mathrm{DM}=30.6 \%$ (as fed) $\mathrm{OM}=88.7 \% ; \mathrm{NDF}=42.6 \%$; indigestible $\mathrm{NDF}$ (iNDF) $=25.2 \%$; potentially digestible $\mathrm{NDF}(\mathrm{pdNDF})=17.4 \%$; starch $=4.0 \%, \mathrm{CP}=20.5 \%$ (DM basis).

${ }^{3} \mathrm{DM}=43.5 \%$ (as fed); $\mathrm{OM} 91.9 \% ; \mathrm{NDF}=42.3 \% ; \mathrm{iNDF}=23.0 \% ; \mathrm{pdNDF}=19.3 \% ;$ starch $=1.87 \%=\mathrm{CP}=$ $22.5 \%$ (DM basis).

${ }^{4} \mathrm{DM}=35.3 \%$ (as fed); and $\mathrm{OM} 89.2 \% ; \mathrm{NDF}=48.0 \% ; \mathrm{iNDF}=13.1 \% ; \mathrm{pdNDF}=34.9 \% ;$ starch $=2.3 \%=\mathrm{CP}$ $=20.4 \%$ (DM basis).

${ }^{5} \mathrm{DM}=33.7 \%$ (as fed); and $\mathrm{OM} 90.3 \% ; \mathrm{NDF}=58.2 \% ; \mathrm{iNDF}=16.1 \% ; \mathrm{pdNDF}=42.1 \% ;$ starch $=1.37 \%=$ $\mathrm{CP}=11.4 \%$ (DM basis)

${ }^{6}$ Experiment 1 = vitamin and mineral mix contained, on a DM basis, $11.7 \%$ dicalcium phosphate, $11.1 \%$ tracemineral premix, $8.8 \%$ sodium bicarbonate, $2.3 \%$ magnesium oxide, $134.3 \mathrm{kIU} / \mathrm{kg}$ of vitamin $\mathrm{A}, 35.53 \mathrm{kIU} / \mathrm{kg}$ of vitamin $\mathrm{D}, 895.5 \mathrm{kIU} / \mathrm{kg}$ of vitamin $\mathrm{E}$, and $65.2 \%$ ground corn grain as a carrier.

${ }^{7}$ Experiment $2=$ vitamin and mineral mix contained, on a DM basis, $16.5 \%$ sodium bicarbonate, $14.2 \%$ magnesium sulfate, $7.1 \%$ salt, $5.8 \%$ dicalcium phosphate, $2.4 \%$ trace-mineral premix, $0.4 \%$ vitamin $\mathrm{A}, 0.4 \%$ vitamin $\mathrm{D}, 0.2 \%$ vitamin $\mathrm{E}$, and $53.1 \%$ dry ground corn as a carrier.

${ }^{8}$ West Central Soy, Ralston, IA.

${ }^{9} \mathrm{Sum}$ of the molar concentrations of niacin and nicotinamide; expressed as niacin equivalents.

${ }^{10} \mathrm{Sum}$ of the molar concentrations of pyridoxamine, pyridoxal, and pyridoxine; expressed as pyridoxine equivalents.

${ }^{11} \mathrm{ND}=$ not detected. 
mixed with $225 \mu \mathrm{L}$ of oxidative solution $[175 \mu \mathrm{L}$ of $50 \%$ $\mathrm{NaOH}$ (No. S318, Fisher Scientific) and $50 \mu \mathrm{L}$ of $5 \%$ potassium-ferricyanide (No. 1-3104, Baker, Avantor Performance Materials, Center Valley, PA) per sample]. After incubation ( $5 \mathrm{~min}$ ), approximately $0.25 \mathrm{~g}$ of $\mathrm{NaCl}$ (No. S5886, Sigma-Aldrich) was added to each tube. Following mixing, $2 \mathrm{~mL}$ of 2-butanol (No. A398, Fisher Scientific) were added, the samples were shaken for 1 min, and then $10 \mu \mathrm{L}$ were injected into the HPLC. The analysis was carried out on a Polaris- $\mathrm{NH}_{2}$ column $(250 \mathrm{~mm} \times 4.6 \mathrm{~mm}, 5 \mu \mathrm{m}$; Agilent, Mississauga, ON, Canada) preceded by a guard column (MetaGuard Polaris-NH2, $4.6 \mathrm{~mm}, 3 \mu \mathrm{m}$, Agilent). The mobile phase was composed of $250 \mathrm{~mL}$ of potassium hydrogen phosphate (No. P5379, Sigma-Aldrich) buffer and 750 $\mathrm{mL}$ of acetonitrile (No. A998, Fisher Scientific) at a flow rate of $1.5 \mathrm{~mL} / \mathrm{min}$, with the fluorimetric detection system adjusted at 425 and $370 \mathrm{~nm}$ for emission and excitation, respectively. The total HPLC run time required per sample was set to $7 \mathrm{~min}$.

Riboflavin. Riboflavin concentrations were determined according to a method adapted from Giguère et al. (2002). Initial solutions of riboflavin $(2,656 \mu M$; No. R4500, Sigma-Aldrich) and flavin-adenine dinucleotide (FAD; 2,411 $\mu M$; No. F6625, Sigma-Aldrich) were used to obtain standard curves with 6 concentrations (5.3, 8.0, 13.3, 26.6, 53.1, and $79.7 \mu M$ and 5.3, 8.0, 13.3, 26.5, 53.0, and $79.6 \mu M$ for riboflavin and $\mathrm{FAD}$, respectively). All forms of the vitamin were transformed into riboflavin for analysis and the FAD curve was made to confirm the efficiency of the reaction. Feed and digesta samples $(0.2 \mathrm{~g})$ were acidified in $10 \mathrm{~mL}$ of $0.1 \mathrm{M} \mathrm{HCl}$ (No. A144, Fisher Scientific) in 50-mL polypropylene conical tubes and autoclaved for $30 \mathrm{~min}$ at $100^{\circ} \mathrm{C}$. After cooling in an ice bath, $\mathrm{pH}$ was adjusted to 4.5 with 4.0 $M$ sodium acetate buffer and $500 \mu \mathrm{L}$ of $1 \%$ reduced glutathione were added in each tube. Next, $1 \mathrm{~mL}$ of a trienzyme solution as used for thiamin analysis was added. The samples were incubated ( $1 \mathrm{~h} 25 \mathrm{~min})$ in an ultrasonic bath (Ultrasonic Cleaners, $40 \mathrm{kHz}$, ColeParmer) and then autoclaved $\left(100^{\circ} \mathrm{C}, 5 \mathrm{~min}\right)$. After cooling in an ice bath, the volume was completed to $15 \mathrm{~mL}$ with ultrapure water and centrifuged $(900 \times g$, $\left.10 \mathrm{~min}, 4^{\circ} \mathrm{C}\right)$. The supernatant $(500 \mu \mathrm{L})$ was combined with $200 \mu \mathrm{L}$ of $15 \%$ perchloric acid (No. 77227, SigmaAldrich) solution, and samples were then boiled for 10 min. Following centrifugation $\left(900 \times \mathrm{g}, 10 \mathrm{~min}, 4^{\circ} \mathrm{C}\right)$, the supernatant $(400 \mu \mathrm{L})$ was mixed with $200 \mu \mathrm{L}$ of 4.0 $M$ sodium acetate and $25 \mu \mathrm{L}$ of $2 \%$ acid phosphatase [20 $\mathrm{mg}$ of phosphatase per $\mathrm{mL}$ of $50 \mathrm{mM}$ ammonium acetate (No. 372331, Sigma-Aldrich) buffer (pH 4.0)]. Samples were incubated $\left(37^{\circ} \mathrm{C}, 18 \mathrm{~h}\right)$ in a water bath to convert FAD into riboflavin. Following centrifugation $\left(10,000 \times g, 10 \mathrm{~min}, 4^{\circ} \mathrm{C}\right)$, the supernatants were injected into the HPLC. Analysis was carried out with a Pursuit $5 \mu \mathrm{m} \mathrm{C} 18$ column $(150 \times 4.6 \mathrm{~mm}$; Varian, Mississauga, ON, Canada) preceded by a guard column (MetaGuard Pursuit $5 \mu \mathrm{m} \mathrm{C18,} 4.6 \mathrm{~mm}$; Agilent). The mobile phase was composed of $80 \mathrm{~mL}$ of ammonium acetate buffer ( $\mathrm{pH} 4.0), 800 \mathrm{~mL}$ of ultrapure water, and $200 \mathrm{~mL}$ of acetonitrile at a flow rate of $1.0 \mathrm{~mL} / \mathrm{min}$ and the fluorimetric detection system adjusted at 520 and $450 \mathrm{~nm}$ for emission and excitation, respectively. The total HPLC run time required per sample was set to 8 min.

Niacin. Concentrations of the 2 forms of niacin, nicotinic acid (NA) and nicotinamide (NAM), were analyzed by HPLC with fluorimetric detection based on adaptation of methods of Mawatari et al. (1991), Lahély et al. (1999), and Ndaw et al. (2002). Standard solutions were prepared by dissolving $0.01 \mathrm{~g}$ of NA (No. 72311, Sigma-Aldrich) and NAM (No. N5535, SigmaAldrich) in $100 \mathrm{~mL}$ of ultrapure water. Six concentrations of NA $(5.0,10.2,20.3,40.6,81.2$, and $100 \mu M)$ and NAM $(5.2,10.2,20.5,41.0,81.9$, and $100.00 \mu M)$ were used for the standard curves. Then, $0.2 \mathrm{~g}$ of sample, feed or digesta, was acidified in $10 \mathrm{~mL}$ of $0.1 \mathrm{M} \mathrm{HCl}$ in a $50-\mathrm{mL}$ polypropylene conical tube and autoclaved 30 min at $100^{\circ} \mathrm{C}$. After cooling in an ice bath, $\mathrm{pH}$ was adjusted to 4.5 with $4.0 \mathrm{M}$ sodium acetate buffer and $500 \mu \mathrm{L}$ of $1 \%$ reduced glutathione were added in each sample. Next, the same trienzyme mix as used for thiamin analyses was applied. The samples were incubated (1 h 25 min) in an ultrasonic bath (Ultrasonic Cleaners, $40 \mathrm{kHz}$, Cole-Parmer) and then autoclaved $\left(100^{\circ} \mathrm{C}, 5\right.$ min). After cooling in an ice bath, the volume was adjusted to $15 \mathrm{~mL}$ with ultrapure water and centrifuged $\left(900 \times g, 10 \mathrm{~min}, 4^{\circ} \mathrm{C}\right)$. The supernatant $(2 \mathrm{~mL})$ was collected, of which $20 \mu \mathrm{L}$ were injected into the HPLC. Samples were run through a Pursuit $5 \mu \mathrm{m} \mathrm{C18}$ column $(150 \times 4.6 \mathrm{~mm}$; Agilent $)$ preceded by a guard column

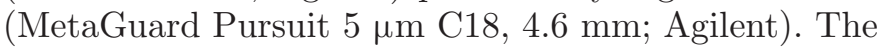
postcolumn photochemical reaction was carried out in a polytetra-fluoroethylene tube $(10 \mathrm{~m} \times 0.5 \mathrm{~mm})$, which was wound around a black light (Black-Ray, model XX-20BLB, 300-400 nm with a filter excluding the $254 \mathrm{~nm}$ line, $115 \mathrm{~V}, 60 \mathrm{~Hz}, 60 \mathrm{~A}$; UVP, Upland, CA). The mobile phase consisted of $0.07 \mathrm{M}$ potassium dihydrogen phosphate (No. 60221, Sigma-Aldrich) buffer containing $0.075 M$ hydrogen peroxide (No. H325, Fisher Scientific) and $5.1 \mu M$ copper II sulfate (No. C1297, Sigma-Aldrich). The flow rate was adjusted to $1.5 \mathrm{~mL} / \mathrm{min}$, and the fluorimetric detector operated at an excitation wavelength of $322 \mathrm{~nm}$ and an emission wavelength of $380 \mathrm{~nm}$. The total HPLC run time required per sample was set to $14 \mathrm{~min}$. Total niacin daily intake, duodenal flow, and ARS were the summation of NA and NAM for these variables. 
Vitamin $\boldsymbol{B}_{6}$. The 3 forms of vitamin $\mathrm{B}_{6}$, pyridoxamine (PAM), pyridoxal (PAL), and pyridoxine (PYR), were determined by adaptation of methods described by Srivastava and Beutler (1973) and Matte et al. (1997). Four stock solutions made in ultrapure water $(500 \mu \mathrm{g} / \mathrm{mL})$ of PAM (No. P9380, Sigma-Aldrich), PAL (No. P9130, Sigma-Aldrich), PYR (No. P4722, Sigma-Aldrich), and pyridoxal-5'-phosphate (P5P; No. P9255, Sigma-Aldrich) were diluted (one-tenth for PAM, PAL, and P5P; one-thirtieth for PYR) to obtain standard solutions $(207,246,202$, and $81 \mu M$, respectively). Feed and digesta samples were analyzed for PAM, PAL, and PYR simultaneously, whereas P5P was converted to PAL before analysis. A separate standard curve was made for P5P to validate the efficiency of the transformation into PAL. In a 50-mL polypropylene conical tube, $10 \mathrm{~mL}$ of $0.1 \mathrm{M} \mathrm{H}_{2} \mathrm{SO}_{4}$ were added to $0.2 \mathrm{~g}$ of sample and autoclaved $\left(100^{\circ} \mathrm{C}, 15 \mathrm{~min}\right)$. After cooling in an ice bath, $\mathrm{pH}$ was adjusted to 4.5 with 4.0 $M$ sodium acetate buffer, and $500 \mu \mathrm{L}$ of $1 \%$ reduced glutathione were added in each tube. Next, adapted from the method of Hyun and Tamura (2005), $1 \mathrm{~mL}$ of an aqueous solution of $60 \mathrm{U}$ of papain and 10,167 $\mathrm{U}$ of $\alpha$-amylase was added. The samples were incubated (1 h 25 min) in an ultrasonic bath (Ultrasonic Cleaners, $40 \mathrm{kHz}$, Cole-Parmer) and then autoclaved $\left(100^{\circ} \mathrm{C}\right.$, 5 min). After cooling in an ice bath, the volume was completed to $20 \mathrm{~mL}$ with ultrapure water and centrifuged $\left(900 \times \mathrm{g}, 10 \mathrm{~min}, 4^{\circ} \mathrm{C}\right)$. Immediately following centrifugation, the supernatant $(1 \mathrm{~mL})$ was incubated $\left(37^{\circ} \mathrm{C}, 18 \mathrm{~h}\right)$ with $25 \mu \mathrm{L}$ of $2 \%$ phosphatase acid [20 mg of phosphatase per $\mathrm{mL}$ of ammonium acetate buffer (50 $\mathrm{m} M, \mathrm{pH} 4.0)]$ to convert $\mathrm{P} 5 \mathrm{P}$ into PAL. The samples were then centrifuged $\left(10,000 \times g, 10 \mathrm{~min}, 4^{\circ} \mathrm{C}\right)$ before being injected into the HPLC, using the same model of column as for niacin analyses. The mobile phase for vitamin $\mathrm{B}_{6}$ consisted of $0.09 M$ of $\mathrm{H}_{2} \mathrm{SO}_{4}$ at a flow rate of $1.5 \mathrm{~mL} / \mathrm{min}$. Emission and excitation wavelengths of the fluorimetric detection system were 290 and 395 $\mathrm{nm}$, respectively. The total HPLC run time required per sample was set to 10 min. Total vitamin $B_{6}$ daily intake, duodenal flow, and ARS were the summation of PAM, PAL, and PYR for these variables. Although concentrations of some forms of the vitamin were close to the level of detection, the mean intra-assay coefficient of variation were 4.5 and $3.4 \%$ in feed and digesta, respectively.

Folates. The method of extraction was adapted from AOAC International (2005, method 960.46) using the following extraction solution: $14.2 \mathrm{~g}$ of $\mathrm{Na}_{2} \mathrm{HPO}_{4}$ (No. S375, Fisher Scientific) and $10 \mathrm{~g}$ of citric acid (No. C0759, Sigma-Aldrich) in $1 \mathrm{~L}$ of ultrapure water $(\mathrm{pH}$ 7.3). In a $50-\mathrm{mL}$ polypropylene conical tube, $5 \mathrm{~mL}$ of this phosphate buffer were mixed with $0.1 \mathrm{~g}$ of solid material. According to the method adapted from Hyun and Tamura (2005), $100 \mu \mathrm{L}$ of a papain solution (60 U) made in ultrapure water were added and all samples were incubated $\left(37^{\circ} \mathrm{C}, 1 \mathrm{~h} 30 \mathrm{~min}\right)$. The samples were autoclaved to inactivate the enzyme $\left(100^{\circ} \mathrm{C}, 5 \mathrm{~min}\right)$ and cooled in an ice bath, then $100 \mu \mathrm{L}$ of $\alpha$-amylase (10167 $\mathrm{U})$ and $200 \mu \mathrm{L}$ of conjugase $(5 \mathrm{mg} / \mathrm{mL}$, Pel-Freez Biologicals, Rogers, AR) solutions made in ultrapure water were added. All samples were incubated $\left(37^{\circ} \mathrm{C}, 3 \mathrm{~h}\right)$ before autoclaving $\left(100^{\circ} \mathrm{C}, 5 \mathrm{~min}\right)$. Following cooling at room temperature, the volume was completed to $40 \mathrm{~mL}$ with ultrapure water. Next, the tubes were centrifuged $\left(5,000 \times g, 10 \mathrm{~min}, 4^{\circ} \mathrm{C}\right)$ and the supernatants were used to determine folate concentration using a commercial microbiological microtiter plate test (VitaFast Folic Acid, R-Biopharm Inc.). This procedure used Lactobacillus rhamnosus, which responds to the widest variety of folate biological active forms (Bird and McGlohon, 1972; Tamura et al., 1972).

Vitamin $\boldsymbol{B}_{12}$. The method of extraction was adapted from AOAC International $(2005,952.20)$ using the following extractive solution: $13 \mathrm{~g}$ of $\mathrm{Na}_{2} \mathrm{HPO}_{4}, 12 \mathrm{~g}$ of citric acid, and $10 \mathrm{~g}$ of sodium metabisulfite (No. S244, Fisher Scientific) in $1 \mathrm{~L}$ of ultrapure water. A sample of $0.1 \mathrm{~g}$ of solid material was hydrolyzed with 20 $\mathrm{mL}$ of extractive solution, and $150 \mu \mathrm{L}$ of $0.1 \mathrm{M} \mathrm{NaCN}$ (No. 205222, Sigma-Aldrich) were added before autoclaving $\left(100^{\circ} \mathrm{C}, 10 \mathrm{~min}\right)$. Subsequently, the tubes were cooled at room temperature and the $\mathrm{pH}$ was adjusted with $3.3 \mathrm{M} \mathrm{NaOH}$ at 6.2 to 6.5 . The final volume was completed at $30 \mathrm{~mL}$ with ultrapure water and samples were centrifuged $\left(3,000 \times g, 10 \mathrm{~min}, 4^{\circ} \mathrm{C}\right)$. A volume of $200 \mu \mathrm{L}$ of the supernatant was used to determine the concentration of the biologically active form of vitamin $\mathrm{B}_{12}$ using a commercial kit [SimulTRAC-S Vitamin $\mathrm{B}_{12}$ $\left({ }^{57} \mathrm{Co}\right) /$ Folate $\left({ }^{125} \mathrm{I}\right)$, MP Biomedicals].

\section{Calculations and Statistical Analyses}

The $\mathrm{B}$ vitamin concentrations in the TMR were the summation of B vitamin concentrations of each ingredient (Table 2) multiplied by the proportion of this ingredient in the TMR, on a DM basis. Daily intakes of each vitamin were calculated as the concentration of each vitamin in the TMR multiplied by the amount of TMR ingested, on a DM basis (Table 3). Calculations of DM duodenal flow (DF) were described by Voelker Linton and Allen (2008; experiment 1) and Kammes and Allen (2012; experiment 2). Duodenal flow of vitamins was calculated as B vitamin concentrations in duodenal digesta multiplied by the daily DM flowing through the 
Table 2. B-vitamin concentrations ( $\mathrm{mg} / \mathrm{kg}$ of DM, unless noted) of ingredients used in the experimental diets

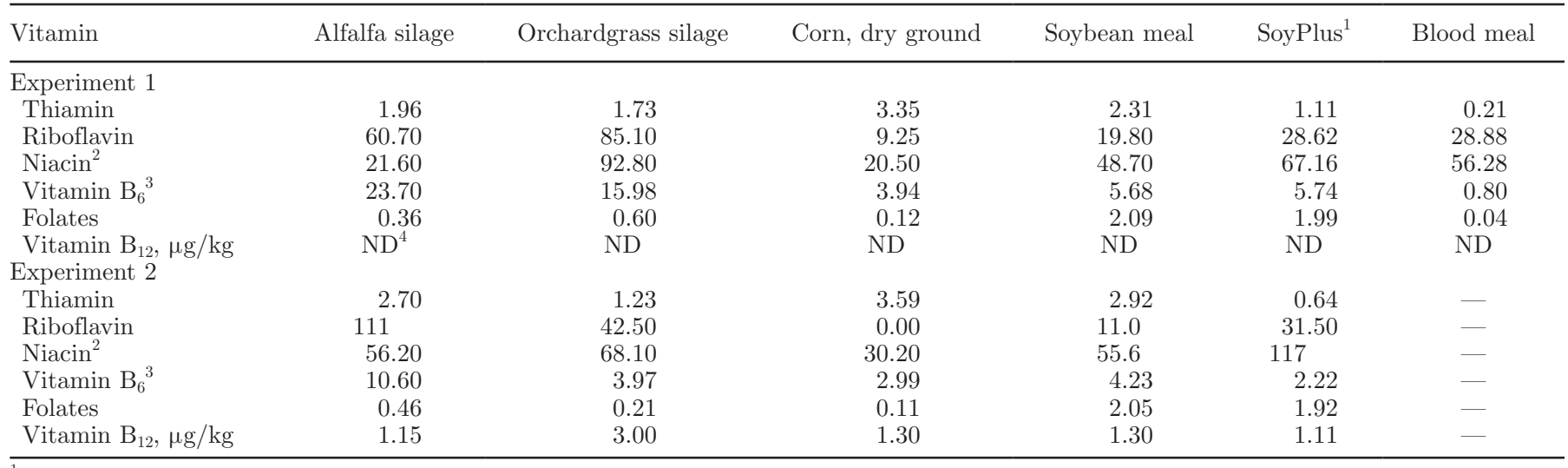

${ }^{1}$ West Central Soy, Ralston, IA.

${ }^{2}$ Sum of the molar concentrations of niacin and nicotinamide; expressed as niacin equivalents.

${ }^{3}$ Sum of the molar concentrations of pyridoxamine, pyridoxal, and pyridoxine; expressed as pyridoxine equivalents.

${ }^{4} \mathrm{ND}=$ not detected.

duodenum. Apparent ruminal synthesis was calculated as DF minus intake.

The data were analyzed separately for the 2 experiments. Daily intake, DF, and ARS for each vitamin, expressed in milligram per day or milligram per kilogram of DMI, were analyzed using the mixed procedure of
SAS (version 9.2; SAS Institute, 2008). The hypothesis that forage family affects responses of $\mathrm{B}$ vitamin daily intake, DF, and ARS was tested using the following model:

$$
Y_{i j k}=\mu+C_{i}+P_{j}+T_{k}+P T_{j k}+\varepsilon_{i j k}
$$

Table 3. Intake, duodenal flow, and apparent ruminal synthesis (ARS) of B vitamins (mg/d) in responses to diets based on alfalfa (AL) or orchardgrass (OG) silages (LS Means) in experiments 1 and 2

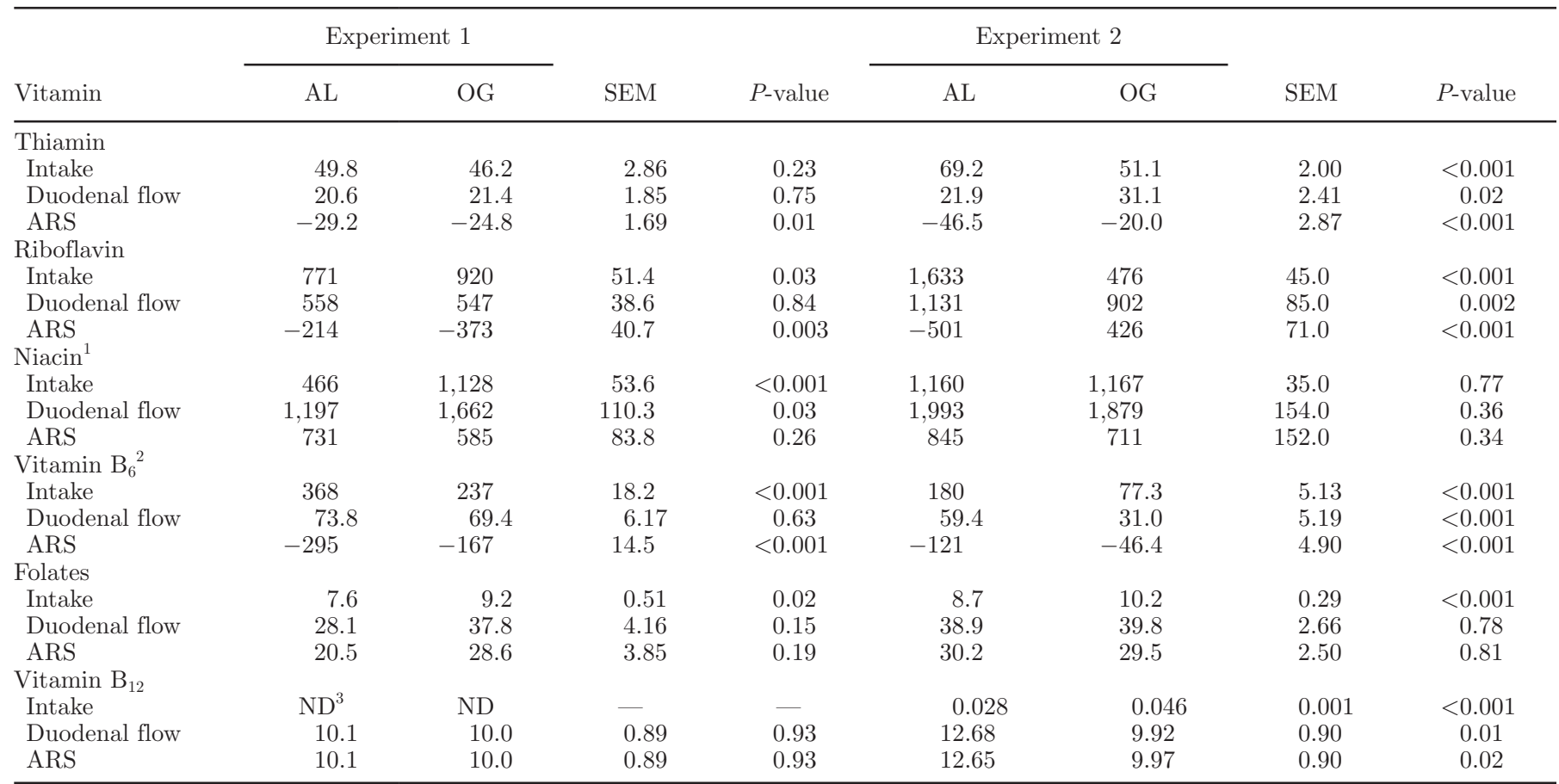

${ }^{1}$ Sum of the molar concentrations of niacin and nicotinamide; expressed as niacin equivalents.

${ }^{2} \mathrm{Sum}$ of the molar concentrations of pyridoxamine, pyridoxal, and pyridoxine; expressed as pyridoxine equivalents.

${ }^{3} \mathrm{ND}=$ not detected. 
Table 4. Duodenal flow and apparent ruminal synthesis (ARS) of B vitamins (mg/kg of DMI) in responses to diets based on alfalfa (AL) or orchardgrass (OG) silages (LSM) in experiments 1 and 2

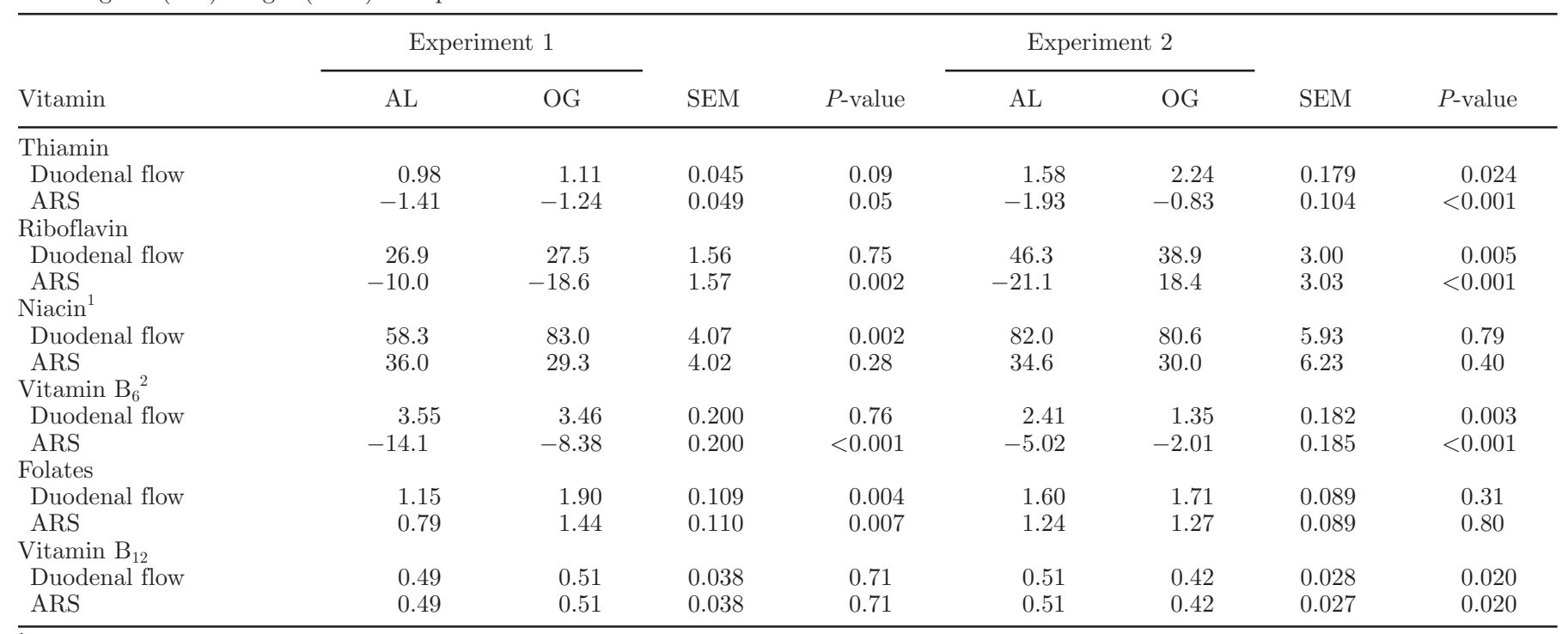

${ }^{1}$ Sum of the molar concentrations of niacin and nicotinamide; expressed as niacin equivalents.

${ }^{2}$ Sum of the molar concentrations of pyridoxamine, pyridoxal, and pyridoxine; expressed as pyridoxine equivalents.

where $Y_{i j k}$ is the dependent variable, $\mu$ is the overall mean, $C_{i}$ is the random effect of cow $(i=1$ to 8 , experiment $1 ; 1$ to 13 , experiment 2$), P_{j}$ is the fixed effect of period $(j=1$ to 2$), T_{k}$ is the fixed effect of treatment $(k=1$ to 2$), P T_{j k}$ is the interaction of period and treatment, and $\varepsilon_{i j k}$ is the residual error. Pearson correlation coefficients were determined using combined data from both experiments. Differences were declared significant at $P \leq 0.05$ and as a tendency at $0.05<P \leq 0.10$.

\section{RESULTS}

Animal performance was presented and discussed previously by Voelker Linton and Allen (2008; experiment 1) and by Kammes and Allen (2012; experiment 2 ). Forage family did not affect neither DMI [experiment $1=20.9$ vs. $20.0(\mathrm{SE}=1.2 ; P=0.25) \mathrm{kg} / \mathrm{d}$; experiment $2=24.2$ vs. $23.2(\mathrm{SE}=0.63 ; P=0.13)$ $\mathrm{kg} / \mathrm{d}$; for AL and $\mathrm{OG}$, respectively] nor DM duodenal flow [experiment $1=12.6$ vs. $13.7(\mathrm{SE}=1.1 ; P=0.50)$ $\mathrm{kg} / \mathrm{d}$; experiment $2: 14.9$ vs. $13.9(\mathrm{SE}=0.62 ; P=0.09)$ $\mathrm{kg} / \mathrm{d}$; for $\mathrm{AL}$ and $\mathrm{OG}$, respectively].

\section{Vitamin Intake}

Orchardgrass diets increased intakes of riboflavin and niacin in experiment 1 , whereas it decreased riboflavin and increased thiamin intakes in experiment $2(P<$ 0.05; Table 3). In both experiments, OG diet decreased vitamin $\mathrm{B}_{6}$ intake and increased folate intake $(P<0.05$; Table 3).

\section{Apparent Ruminal Synthesis and Duodenal Flow}

Apparent ruminal synthesis (expressed as $\mathrm{mg} / \mathrm{kg}$ of DMI; Table 4) of thiamin, vitamin $\mathrm{B}_{6}$, and folates was greater $(P<0.05)$ whereas riboflavin ARS was smaller $(P=0.007)$ for OG in experiment 1 . However, in experiment 2 , ARS of thiamin, riboflavin, and vitamin $\mathrm{B}_{6}$ was greater $(P<0.05)$ whereas vitamin $\mathrm{B}_{12}$ ARS was smaller $(P=0.02)$ for OG. Duodenal flow of niacin and folates (expressed as $\mathrm{mg} / \mathrm{kg}$ of DMI; Table 4) was greater $(P<0.05)$ for $\mathrm{OG}$ in experiment 1 , whereas $\mathrm{DF}$ of thiamin was smaller $(P=0.02)$ and riboflavin, vitamin $\mathrm{B}_{6}$, and vitamin $\mathrm{B}_{12} \mathrm{DF}$ were greater $(P<0.05)$ for $\mathrm{AL}$ in experiment 2. Correlations between each $\mathrm{B}$ vitamin ARS and dietary and digestive parameters are reported in Table 5.

\section{DISCUSSION}

Plant maturity at harvest differed between the 2 experiments (experiment 1: early bud stage and early boot stage; experiment 2: early to midbloom and early head for AL and OG respectively). It is well known that nutrient composition of forage changes with advancing maturity (Jung and Allen, 1995; Yu et al., 2003; Yari et al., 2012), but little information is available on forage vitamin composition. In the present study, delaying harvest numerically decreased concentrations of all $\mathrm{B}$ vitamins in OG silage, whereas it increased thiamin, riboflavin, niacin, and folate concentrations but lowered vitamin $\mathrm{B}_{6}$ concentrations in $\mathrm{AL}$ silage. 
Calculation of ARS of $\mathrm{B}$ vitamins does not allow evaluating the confounded effects of microbial use, ruminal degradation, and potential absorption of $\mathrm{B}$ vitamins across the rumen wall. A lack of information exists on the extent of microbial use and degradation of $\mathrm{B}$ vitamins in the rumen, but some studies have shown that ruminal absorption is negligible. Hoeller et al. (1977) demonstrated the impermeability of the rumen wall to thiamin under in vitro conditions; however, according to Rérat et al. (1959), B vitamins in solution in an empty rumen can be absorbed across the rumen wall, but in fed animals, the amount absorbed from the rumen is negligible because B vitamins are mostly sequestered within bacteria. This observation is supported by findings from Santschi et al. (2005b), who reported that B vitamin concentrations are up to 5,000 fold higher in bacteria than in particle-free supernatant. Apparent ruminal synthesis probably underestimates the amounts of vitamins synthesized by ruminal microflora. Nevertheless, this calculated parameter allows comparisons among treatments and estimation of the relative importance of ruminal microflora for vitamin supply.

\section{Thiamin}

The amount of thiamin flowing to the duodenum was less than the daily intake, indicating losses in the upper gastrointestinal tract, possibly due to degradation of the vitamin by the ruminal microflora. These losses were greater in AL diets, with $73 \%$ more thiamin degraded than with OG on average. Ruminal balance of thiamin varied from -1.03 to $-1.67 \mathrm{mg} / \mathrm{kg}$ of DMI, on average, for $\mathrm{OG}$ and $\mathrm{AL}$, respectively. These results differed from the values calculated from Castagnino et al. (2014; $4.35 \mathrm{mg} / \mathrm{kg}$ of DMI), Santschi et al. (2005a; $1.3 \mathrm{mg} / \mathrm{kg}$ of DMI), Schwab et al. (2006; $2.5 \mathrm{mg} / \mathrm{kg}$ of DMI), Breves et al. (1981; $3.72 \mathrm{mg} / \mathrm{kg}$ of DMI), and Steinberg and Kaufmann (1977; $5 \mathrm{mg} / \mathrm{kg}$ of DMI), all of which reported positive balance of ARS. Nevertheless, Miller et al. (1986) also observed ruminal degradation of thiamin $(-1.30 \mathrm{mg} / \mathrm{kg}$ of DMI). Edwin and Jackman (1982) suggested that ruminal degradation of thiamin could be due to the presence of microbial thiaminase, which may be directly related to ruminal pH (Brent, 1976). However, when combining data from both experiments, thiamin ruminal degradation was not correlated with daily mean ruminal $\mathrm{pH}$ in the current studies (Table 5). In the present experiments, thiamin ARS was negatively correlated with OM intake and true ruminal degradation of OM, as well as with total VFA concentration, and tended to be correlated negatively with microbial $\mathrm{N}$ flow to duodenum. These correlations indicate that, under the present experimental conditions, increasing microbial biomass activity increased thiamin degradation in the rumen. On the contrary,

Table 5. Pearson correlations coefficients between apparent ruminal synthesis (ARS) of B vitamins and dietary and digestive parameters

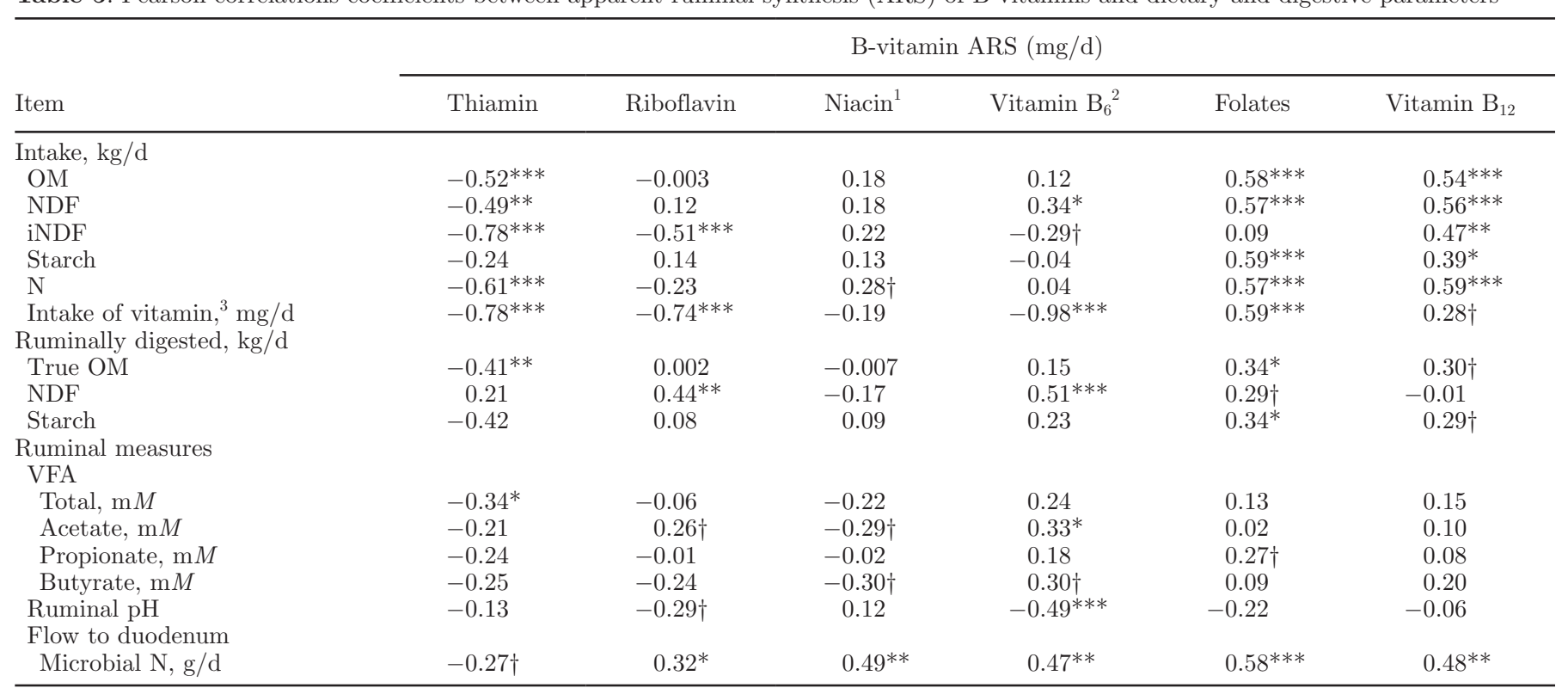

${ }^{1}$ Sum of the molar concentrations of niacin and nicotinamide; expressed as niacin equivalents.

${ }^{2}$ Sum of the molar concentrations of pyridoxamine, pyridoxal, and pyridoxine; expressed as pyridoxine equivalents.

${ }^{3}$ Intake of the corresponding B vitamin.

$\dagger P<0.10,{ }^{*} P<0.05,{ }^{* *} P<0.01$, and ${ }^{* * *} P<0.001$. 
Schwab et al. (2006) observed positive correlations between thiamin ARS and these variables. Daily thiamin intake in the present experiments varied from 46 to 69 $\mathrm{mg} / \mathrm{d}$ and were in the higher range reported by Schwab et al. (2006), 27 to $46 \mathrm{mg} /$ d. However, thiamin DF reported by Schwab et al. (2006) was more than 3 times greater than in the present experiments, 71 to 97 versus 21 to $31 \mathrm{mg} / \mathrm{d}$, respectively, which explains the difference in ARS between these studies. The proportion of forage in diets used in experiments 1 (48 and 53\%) and 2 (43 and $60 \%$ ) were within the range studied by Schwab et al. (2006), who compared diets with 35 and $60 \%$ forage. Nevertheless, ingredient and nutrient compositions differed between these studies. For example, NDF concentrations were greater (35 to $47 \%$ of DM vs. 27 to $30 \%$ DM) but starch concentrations were smaller (5.2 to 20.7 vs. 27.3 to $32.1 \%$ of DM) in diets studied by Schwab et al. (2006) than in those used in experiments 1 and 2. Differences between the studies are probably due to nutrient composition and how it affects ruminal microorganism activity although the present results do not allow to identify the nutrient(s) explaining these differences.

\section{Riboflavin}

As for thiamin, we also observed a disappearance of riboflavin before the duodenum in experiment 1 . In experiment 2 the AL treatment also presented a negative balance $(-21.05 \mathrm{mg} / \mathrm{kg}$ of $\mathrm{DMI})$, whereas in the $\mathrm{OG}$ treatment the ruminal balance was positive. Previous studies reported positive values for ARS (Santschi et al., 2005a, $13.48 \mathrm{mg} / \mathrm{kg}$ of DMI; Schwab et al., 2006, $11.69 \mathrm{mg} / \mathrm{kg}$ of DMI; and Miller et al., 1986, 8.88 $\mathrm{mg} / \mathrm{kg}$ of DMI). Among the numerous differences in ingredient and nutrient composition of diets used in the studies cited above, it is noteworthy that in our study riboflavin intake was 8 to 38 fold greater than in those studies suggesting a regulatory mechanism by the ruminal microbiota. This hypothesis is supported by the observations that riboflavin ARS was negatively correlated with its intake and that a positive niacin ruminal balance was observed only for the treatment with the lowest vitamin intake (experiment 2, OG diet). Riboflavin ARS was positively correlated with ruminally digested NDF and microbial N flow to the duodenum. A trend for a positive correlation was also noted with the acetate concentration in the rumen and a negative correlation with the rumen $\mathrm{pH}$. These facts may indicate that the fibrolytic bacteria are primarily responsible for the synthesis of riboflavin in the rumen.

\section{Niacin}

In spite of a marked difference in niacin intake in experiment 1 , forage family did not affect niacin ARS in both experiments. Using grass-legume and corn silages as forages, Santschi et al. (2005a) reported niacin DF and ARS of 140 and $112 \mathrm{mg} / \mathrm{kg}$ of DMI, respectively. With diets containing corn silage, alfalfa, and grass hay, Schwab et al. (2006) observed niacin DF varying from 105 to $129 \mathrm{mg} / \mathrm{kg}$ of DMI, and ARS from 40 to $70 \mathrm{mg} /$ $\mathrm{kg}$ of DMI. Those values are higher than observed in both current experiments. Contrary to the other studied vitamins, niacin ARS was not correlated with its intake. A positive correlation was noted between niacin ARS and microbial $\mathrm{N}$ flow to the duodenum, as previously observed by Schwab et al. (2006), and a positive trend with $\mathrm{N}$ intake. However, niacin ARS tended to be negatively correlated with concentrations of acetate and butyrate in the rumen. These correlations suggest that niacin ARS is increased when microbial biomass activity is raised.

\section{Vitamin $B_{6}$}

Around $63 \%$ of the vitamin $\mathrm{B}_{6}$ ingested was used or degraded by the rumen microbes in experiment 2 . This effect was greater and different between treatments $(80$ vs $71 \%$ for $\mathrm{AL}$ and $\mathrm{OG}$, respectively) in experiment 1. Similarly, Santschi et al. (2005a) reported negative daily $\mathrm{B}_{6}$ ARS $(-0.71 \mathrm{mg} / \mathrm{kg}$ of DMI), whereas Schwab et al. (2006) observed positive ARS $(1.13 \mathrm{mg} / \mathrm{kg}$ of DMI). As for thiamin and riboflavin, vitamin $\mathrm{B}_{6}$ ARS was negatively correlated with its intake. Positive correlations were observed between vitamin $\mathrm{B}_{6}$ ARS and NDF intake, NDF digested in the rumen, acetate and butyrate concentrations in the rumen, and microbial $\mathrm{N}$ flow to the duodenum. A negative correlation was noted between vitamin $\mathrm{B}_{6}$ ARS and rumen $\mathrm{pH}$. Synthesis of this vitamin in the rumen may therefore also be linked to fibrolytic bacterial activity.

\section{Folates}

When averaged across diets, daily folate ARS was $1.19 \mathrm{mg} / \mathrm{kg}$ of DMI, which is slightly greater than values reported by Santschi et al. (2005a; $1.06 \mathrm{mg} / \mathrm{kg}$ of DMI) and Schwab et al. (2006; ranging from 0.72 to $0.91 \mathrm{mg} / \mathrm{kg}$ of DMI). However, the proportion of folates in DF due to ARS observed by those authors was similar (ranging from 51 to $76 \%$ ) to our experiments (75\%, on average). The OG diet increased folate intake mainly due to the difference in soybean meal contribution between diets. Unlike thiamin, riboflavin, and 
vitamin $\mathrm{B}_{6}$, a positive correlation was observed between folate ingestion and its ARS. Folate ARS increased with nutrient (OM, NDF, starch, and N) intakes and the amounts digested in the rumen, as well as with ruminal propionate concentration and microbial $\mathrm{N}$ flow to the duodenum. Similar relationships were observed by Schwab et al. (2006), indicating that increasing the amount of substrates in rumen increases microbial folate synthesis.

\section{Vitamin $B_{12}$}

Unlike other $\mathrm{B}$ vitamins, vitamin $\mathrm{B}_{12}$ is not synthesized by plants. Therefore, the amount of vitamin $\mathrm{B}_{12}$ in diets is likely due to the bacterial synthesis occurring during silage fermentation or to contamination by soil microorganisms (McDowell, 2000). Production of vitamin $B_{12}$ in the rumen plays a very important role in cow nutrition because it represents, on average, $99 \%$ of the amount reaching the sites of absorption. Vitamin $\mathrm{B}_{12}$ ARS varied from 0.42 to $0.51 \mathrm{mg} / \mathrm{kg}$ of DMI and was similar to $0.41 \mathrm{mg} / \mathrm{kg}$ of DMI reported by Castagnino et al. (2014). However, these values were much less than the average 3.69 and $3.93 \mathrm{mg} / \mathrm{kg}$ of DMI reported by Santschi et al., (2005a) and Schwab et al. (2006), respectively. As for folates, ARS of vitamin $B_{12}$ was positively correlated with nutrient intakes and microbial $\mathrm{N}$ flow to duodenum, which indicates that vitamin $\mathrm{B}_{12}$ ARS is closely linked to microbial biomass activity.

\section{CONCLUSIONS}

Diets based on alfalfa silage resulted in a greater degradation of thiamin and vitamin $\mathrm{B}_{6}$ in the rumen. Apparent ruminal synthesis of niacin was not affected by forage family, whereas the effect of family forage on ARS of riboflavin, folates, and vitamin $\mathrm{B}_{12}$ differed between experiments. Based on the calculated correlations, fibrolytic microorganisms are likely involved in riboflavin and vitamin $\mathrm{B}_{6}$ ARS. Moreover, ruminal microorganisms synthesized more or degraded less thiamin, riboflavin, and vitamin $\mathrm{B}_{6}$ when the amount of vitamin ingested was limited, possibly in an attempt to fulfill their requirements. Apparent ruminal synthesis of folates and vitamin $\mathrm{B}_{12}$ appear to be related to nutrient intake and microbial biomass activity. Results from the present experiments demonstrated that changes in diet composition affect the microbial population in the rumen and their B vitamin metabolism. Nevertheless, results are too limited to allow for the identification of the factor(s) responsible for these changes.

\section{ACKNOWLEDGMENTS}

The authors thank Chrystiane Plante (Agriculture and Agri-Food Canada, Sherbrooke, QC, Canada) for her technical support; during the last 2 decades she developed and validated the methods for B-vitamin analyses described in the present paper. This study was financially supported by the Programme de recherche en partenariat pour l'innovation en production et transformation laitière Novalait-AAC-FRQ-NTMAPAQ (Novalait, Fonds de recherche du Québec, Nature et Technologies, Agriculture et Agroalimentaire Canada, Ministère de l'Agriculture, des Pêcheries et de l'Alimentation du Québec, Québec, Québec, Canada).

\section{REFERENCES}

Abel, H., I. Immig, C. D. Gomez, and W. Steinberg. 2001. Research note: Effect of increasing dietary concentrate levels on microbial biotin metabolism in the artificial rumen simulation system (RUSITEC). Arch. Tierenahr. 55:371-376. http://dx.doi. org/10.1080/17450390109386203.

AOAC International. 2005. Official Methods of Analysis. 18th ed. AOAC International, Gaithersburg, MD.

Bechdel, S. I., C. H. Eckles, and L. S. Palmer. 1926. The vitamin B requirement of the calf. J. Dairy Sci. 9:409-438.

Bird, O. D., and V. M. McGlohon. 1972. Differential assays of folic acid in animal tissues. Pages 409-437 in Analytical Microbiology. Vol. 2. F. Kavanagh, ed. Academic Press, New York, NY.

Bötticher, B., and D. Bötticher. 1986. Simple rapid determination of thiamin by a HPLC method in foods, body fluids, urine and faeces. Int. J. Vitam. Nutr. Res. 56:155-159.

Brent, B. E. 1976. Relationship of acidosis to other feedlot ailments. J. Anim. Sci. 43:930-935. http://dx.doi.org/10.2134/ jas1976.434930x.

Breves, G., M. Brandt, H. Hoeller, and K. Rohr. 1981. Flow of thiamin to the duodenum in dairy cows fed different rations. J. Agric. Sci. 96:587-591.

Castagnino, D. S., K. L. Kammes, M. S. Allen, R. Gervais, P. Y. Chouinard, D. E. Santschi, and C. L. Girard. 2014. Apparent synthesis of thiamin and vitamin B12 in rumen of lactating dairy cows fed alfalfa or orchardgrass silages at different maturity stages. J. Dairy Sci. 97(E-Suppl. 1):1876

Chen, B., C. Wang, V. M. Wang, and J. X. Liu. 2011. Effect of biotin on milk performance of dairy cattle: a meta-analysis. J. Dairy Sci. 94:3537-3546. http://dx.doi.org/10.3168/jds.2010-3764.

Combs, G. F. 2012. The Vitamins. 4th ed. Elsevier Inc., New York, NY

Conrad, H. E., and J. W. Hibbs. 1954. A high roughage system for raising calves based on early rumen development. IV. Synthesis of thiamin and riboflavin in the rumen as influenced by the ratio of hay to grain fed and initiation of dry feed consumption. J. Dairy Sci. 37:512-522. http://dx.doi.org/10.3168/jds.S00220302(54)91292-8.

Edwin, E. E., and R. Jackman. 1982. Ruminant thiamine requirement in perspective. Vet. Res. Commun. 5:237-250. http://dx.doi. org/10.1007/BF02214990.

Giguère, A., C. L. Girard, and J. J. Matte. 2002. Erythrocyte glutathione reductase activity and riboflavin nutritional status in early-weaned piglets. Int. J. Vitam. Nutr. Res. 72:383-387. http:// dx.doi.org/10.1024/0300-9831.72.6.383.

Girard, C. L., H. Lapierre, J. J. Matte, and G. E. Lobley. 2005. Effects of dietary supplements of folic acid and rumen-protected methionine on lactational performance and folate metabolism of 
dairy cows. J. Dairy Sci. 88:660-670. http://dx.doi.org/10.3168/ jds.S0022-0302(05)72730-2.

Girard, C. L., and J. J. Matte. 1998. Dietary supplements of folic acid during lactation: Effects on performance of dairy cows. J. Dairy Sci. 81:1412-1419. http://dx.doi.org/10.3168/jds.S00220302(98)75705-4.

Girard, C. L., and J. J. Matte. 2005. Effects of intramuscular injections of vitamin $\mathrm{B}_{12}$ on lactation performance of dairy cows fed dietary supplements of folic acid and rumen-protected methionine. J. Dairy Sci. 88:671-676. http://dx.doi.org/10.3168/jds.S00220302(05)72731-4.

Hayes, B. W., G. E. Mitchell Jr., C. O. Little, and N. W. Bradley. 1966. Concentrations of B vitamins in ruminal fluid of steers fed different levels and physical forms of hay and grains. J. Anim. Sci. 25:539-542.

Hoeller, H., M. Fecke, and K. Schaller. 1977. Permeability to thiamin of the sheep rumen wall in vitro. J. Anim. Sci. 44:158-161. http:// dx.doi.org/10.2134/jas1977.441158x.

Hyun, T. H., and T. Tamura. 2005. Trienzyme extraction in combination with microbiologic assay in food folate analysis: An updated review. Exp. Biol. Med. (Maywood) 230:444-454.

Jakobsen, J. 2008. Optimisation of the determination of thiamin, 2-(1-hydroxyethyl) thiamin, and riboflavin in food samples by use of HPLC. Food Chem. 106:1209-1217. http://dx.doi.org/10.1016/j. foodchem.2007.06.008

Joy, M. T., E. J. DePeters, J. G. Fadel, and R. A. Zinn. 1997. Effects of corn processing on the site and extent of digestion in lactating cows. J. Dairy Sci. 80:2087-2097. http://dx.doi.org/10.3168/jds. S0022-0302(97)76154-X.

Jung, H. G., and M. S. Allen. 1995. Characteristics of plant cell walls affecting intake and digestibility of forages by ruminants. J. Anim. Sci. 73:2774-2790.

Kammes, K. L., and M. S. Allen. 2012. Nutrient demand interacts with forage family to affect digestion responses in dairy cows. J. Dairy Sci. 95:3269-3287. http://dx.doi.org/10.3168/jds.2011-5021.

Kon, S. K., and J. W. G. Porter. 1954. The B vitamin content of the rumen of steers given various diets. Proc. Nutr. Soc. 12:12.

Lahély, S., M. Bergaentzlé, and C. Hasselmann. 1999. Fluorimetric determination of niacin in foods by high-performance liquid chromatography with post-column derivatization. Food Chem. 65:129133. http://dx.doi.org/10.1016/S0308-8146(98)00182-4.

Matte, J. J., A. A. Ponter, and B. Sève. 1997. Effects of chronic parental pyridoxine and acute enteric tryptophan on pyridoxine status, glycemia and insulinemia stimulated by enteric glucose in weanling piglets. Can. J. Anim. Sci. 77:663-668. http://dx.doi.org/10.4141/ A97-013.

Mawatari, K., F. Iinuma, and M. Watanabe. 1991. Determination of nicotinic-acid and nicotinamide in human serum by high-performance liquid-chromatography with postcolumn ultraviolet-irradiation and fluorescence detection. Anal. Sci. 7:733-736. http:// dx.doi.org/10.2116/analsci.7.733.

McDowell, L. R. 2000. Vitamins in Animal and Human Nutrition. 2nd ed. Iowa State University Press, Ames.

Miller, B. L., J. C. Meiske, and R. D. Goodrich. 1986. Effects of grain source and concentrate level on B-vitamin production and absorption in steers. J. Anim. Sci. 62:473-483. http://dx.doi.org/10.2134/ jas1986.622473x.

Ndaw, S., M. Bergaentzle, D. Aoude-Werner, and C. Hasselmann. 2002. Enzymatic extraction procedure for the liquid chromato- graphic determination of niacin in foodstuffs. Food Chem. 78:129 134. http://dx.doi.org/10.1016/S0308-8146(02)00205-4.

Rérat, A., O. Champigny, and R. Jacquot. 1959. Modalités de l'absorption vitaminique chez les ruminants: Forme et disponibilité des vitamines $\mathrm{B}$ du bol alimentaire aux différents niveaux digestifs. C. R. Acad. Sci. 249:1274-1276.

Rosendo, O., C. R. Staples, L. R. McDowell, L. R. McMahon, L. Badinga, F. G. Martin, F. G. Shearer, J. F. Seymour, and W. M. Wilkinson. 2004. Effects of biotin supplementation on peripartum performance and metabolites of Holstein cows. J. Dairy Sci. 87:25352545. http://dx.doi.org/10.3168/jds.S0022-0302(04)73378-0.

Santschi, D. E., R. Berthiaume, J. J. Matte, A. F. Mustafa, and C. L. Girard. 2005a. Fate of supplementary B-vitamins in the gastrointestinal tract of dairy cows. J. Dairy Sci. 88:2043-2054. http:// dx.doi.org/10.3168/jds.S0022-0302(05)72881-2.

Santschi, D. E., J. Chiquette, R. Berthiaume, R. Martineau, J. J. Matte, A. F. Mustafa, and C. L. Girard. 2005b. Effects of the forage to concentrate ratio on B-vitamin concentrations in different ruminal fractions of dairy cows. Can. J. Anim. Sci. 85:389-399. http://dx.doi.org/10.4141/A05-012.

SAS Institute. 2008. User's Guide: Statistics. Version 9.2. SAS Institute Inc., Cary, NC.

Schwab, E. C., D. Z. Caraviello, and R. D. Shaver. 2005. A metaanalysis of lactation responses to supplemental dietary niacin in dairy cows. Prof. Anim. Sci. 21:239-247.

Schwab, E. C., C. G. Schwab, R. D. Shaver, C. L. Girard, D. E. Putnam, and N. L. Whitehouse. 2006. Dietary forage and nonfiber carbohydrate contents influence B-vitamin intake, duodenal flow, and apparent ruminal synthesis in lactating dairy cows. J. Dairy Sci. 89:174-187. http://dx.doi.org/10.3168/jds.S00220302(06)72082-3.

Shaver, R. D., and M. A. Bal. 2000. Effect of thiamin supplementation on milk production by dairy cows. J. Dairy Sci. 83:2335-2340. http://dx.doi.org/10.3168/jds.S0022-0302(00)75121-6.

Srivastava, S. K., and E. Beutler. 1973. A new fluorometric method for the determination of pyridoxal 5'-phosphate. Biochim. Biophys. Acta 304:765-773. http://dx.doi.org/10.1016/0304-4165(73)90223-

Steinberg, W., and W. Kaufmann. 1977. Investigations on the bacterial thiamine synthesis in the rumen of dairy cows. Z. Tierphysiol. Tierernahr. Futtermittelkd. 39:289-301.

Tamura, T., Y. S. Shin, M. A. Williams, and E. L. R. Stokstad. 1972. Lactobacillus casei response to pteroylpolyglutamates. Anal. Biochem. 49:517-521. http://dx.doi.org/10.1016/00032697(72)90456-3.

Voelker Linton, J. A., and M. S. Allen. 2008. Nutrient demand interacts with forage family to affect intake, and digestion responses in dairy cows. J. Dairy Sci. 91:2694-2701. http://dx.doi.org/10.3168/ jds.2007-0897.

Yari, M., R. Valizadeh, A. A. Naserian, A. Jonker, and P. Yu. 2012. Modeling nutrient availability of alfalfa hay harvested at three stages of maturity and in the afternoon and morning in dairy cows. Anim. Feed Sci. Technol. 178:12-19. http://dx.doi.org/10.1016/j. anifeedsci.2012.09.001.

Yu, P., D. A. Christensen, J. J. McKinnon, and J. D. Markert. 2003. Effect of variety and maturity stage on chemical composition, carbohydrate and protein subfractions, in vitro rumen degradability and energy values of timothy and alfalfa. Can. J. Anim. Sci. 83:279-290. http://dx.doi.org/10.4141/A02-053. 